\title{
Risks of environmental opposition to the investment projects implementation
}

\author{
M.B. Vidrevich, and G.Yu. Pakhalchak \\ Ural State University of Economics, 620144 Yekaterinburg, Russia
}

\begin{abstract}
Investment activity plays a significant role in achieving the strategic goals of the development of society, and has a significant impact on the state of the environmental and economic system. Recently, quite often, the interests of various groups related to the preservation of the environment come into conflict with the need for economic development, and hence the impossibility of investing in this development. In this case, potential or real investors lose the money invested. The purpose of the research is to consider the features of environmental and social risks of implementing investment projects, to consider the features of social and environmental risks and to show the need to take into account social and environmental risks for the implementation of investment projects, as well as suggest ways to minimize them. It is shown that the effectiveness of the implementation of investment projects and the reduction of possible losses of investors can be achieved by real consideration of social and environmental risks. Some instruments to reduce the risks of implementing investment projects are proposed.
\end{abstract}

The development of industrial production leads, on the one hand, to economic growth and, as a consequence, to a change in the quality of human life, on the other hand, causes the depletion of the resource potential and pollution of the planet's natural environment (the living environment of all life on Earth). The fight against the negative impact of human life on the environment has been advancing and positioned in world politics in recent decades as one of the indispensable factors in making key decisions by national governments, global corporations and international institutions. The modern economy is guided by the international concept of sustainable development of the world economic and environmental system, the main idea of which is to ensure the sustainable development of modern society without causing irreversible damage to the natural environment and depriving subsequent generations of people of their vital resources [1]. According to this concept, any decisions at all levels should be made taking into account environmental factors. Thus, the most important condition for the transition of the Russian economy to an innovative type of development is the creation and maintenance of a safe and friendly environment.

Investment activity, which plays a significant role in achieving the strategic goals of the development of society, has a significant impact on the state of the ecological and economic system as a whole [2]. Any investment project (IP) cannot be successfully implemented without interaction between business (represented by an investor, a developer or a designer), government agencies (government bodies, ministries, municipalities) and society (local society represented by an interested public, less often - in the form of international 
community). Often this interaction is two-way: business negotiates with government agencies, while local residents are simply informed.

In order to exclude a conflict of interests between society and business implementing investment projects, there are certain procedures for their coordination. According to the requirements of the law, for the construction of a new or reconstruction of an existing industrial facility, several degrees of coordination are required:

- obtaining approval for the placement of the facility from local authorities;

- conclusion of state environmental expertise;

- consent from local residents in the form of public hearing decisions.

This is a complicated and resource-intensive process, requiring an industrial company to participate in all spheres of civil society activity. Therefore, it is so important to develop mechanisms for the effective interaction of business, government, and society.

The purpose of this work is to consider the features of environmental and social risks of implementing IP, to consider the features of social and environmental risks and to show the need to take into account social and environmental risks for the implementation of investment projects, and also to suggest ways to minimize them.

Any IP, especially associated with the introduction of new industrial technologies, development, reconstruction, modernization of production, has a probable measure of the danger of harming the environment and public health in the form of possible losses over a certain time, i.e. characterized by the presence of elements of environmental uncertainty and environmental risks.

In assessing the state of the environment, the uncertainty factor has a special role. Environmental uncertainty is due to:

- incomplete information on the consequences of the project;

- insufficient assessment of the probability of these consequences;

- the inability to foresee unusual consequences, the occurrence of which is associated with the economic activity of the target project.

The value of the uncertainty factor increases with the scale of the project: the amount of natural resources used the magnitude of the impact, the introduction of new substances into the environment or the removal of new substances from it.

Environmental uncertainty leads to environmental risks. The concept of "environmental risk" in Russia was first introduced and included in the list of basic concepts by the RF Law "On Environmental Protection" [3]. Environmental risk is the probability of an event having adverse consequences for the natural environment and caused by the negative impact of economic and other activities, natural and man-made emergencies. The law does not contain any mechanisms for identifying environmental risks, or the procedure for assessing them, nor instruments for managing them.

Environmental aspects of IP, according to the Guidelines for assessing the effectiveness of investment projects [4] (currently the main document that determines the procedure for calculating the effectiveness of IP), as a rule, relate to external effects. There are no relevant requirements for their accounting, despite the fact that in order to ensure sustainable development, project developers and customers are required to identify the main economic, environmental and social aspects of life [4].

In the current economic environment, marked by globalization and the growing interdependence between technological progress and the environment, it has become universally recognized that environmental risk management is an economic and social priority.

The environmental risk assessment of the project is entrusted to the state environmental expertise, which establishes the conformity of the project documentation in part, justifying the compliance of the planned economic and other activities with the legislation in the field 
of environmental protection, in order to prevent the negative impact of this activity on it. If the permissible environmental risk is exceeded, the project shall be rejected.

Environmental risk tolerance criteria:

- minimization of environmental losses;

- real possibility of their recovery;

- no harm to human health;

- proportionality of environmental damage and economic effect.

Environmental risks are usually caused by design errors, violations of technological regulations, insufficiently developed solutions for waste disposal, lack of necessary material, raw materials and other resources, insufficient legal and information support for the project. They are fraught with man-made accidents, poisoning with dangerous substances of the environment and, as a result, causing damage to the environment, dangerous diseases, increased mortality, and a decrease in the age of survival of the population. The scale of the consequences may be very small and inconspicuous, or it may affect the population of several countries. A typical example is the cyanide leak in Baia Mare (Romania) on 30 January 2000, which resulted in the death of a large number of fish in the waters of Hungary and Yugoslavia. This environmental disaster is considered the most serious in Europe after Chernobyl [5].

Environmental risks significantly reduce the efficiency of investments, which is not only related to the reality of their return, but also to the environmental effects that were planned during the preparation of the project.

Environmental risk assessment allows to:

- identify potential environmental risks, eliminate or minimize them;

- predict the onset of adverse effects, prevent or minimize the likelihood of their occurrence;

- receive quantitative and qualitative indicators of adverse effects;

- prevent accidents, harm to public health, environmental components, damage to the reputation of the entity implementing the project.

A public environmental expertise, which allows to assess the quality of preparation of project documentation and to draw conclusions about the possible environmental, socioecological and economic consequences of the project, is an effective tool for protecting the environmental rights of citizens and public control. Initiators of a public environmental expertise are required to register a public expertise with local authorities.

The correct response to environmental risks is to consider risk as one of the costs when calculating their expected values, or to continue research and not make decisions on the project without sufficiently convincing forecasts.

Social risks of IP implementation are associated with the social component of investment activity. They influence the implementation of the project by forming public opinion, holding strikes, debates, etc. This means that it is impossible to accurately predict the behavior of individuals who will be affected by the outcome or progress of the project.

Social and environmental risks can be distinguished as a separate category of risks of the investment project. We understand them as the risks of opposition to the implementation of the project by the interested public, associated with fears of exceeding the permissible environmental risk.

In recent decades, in Russia, as in other countries, during the implementation of investment projects, the case of the active promotion of environmental and social requirements by the interested public has become more frequent. It is with her that she has to establish interaction and enter into dialogue with the authorities and business circles. And it is the interested public that seeks to exercise their rights in environmental and socially significant decisions. International and local public organizations, using the norms of the socalled "environmental law", put pressure on industry and state development institutions through environmental protest tools. However, under the guise of environmental initiatives, 
financial and economic or political, often non-environmental, tasks are often addressed. So, out of 150 foreign agents, 29 turned out to be environmental organizations [6].

The ambiguity of the actions of environmental organizations and individual activists is due to a number of reasons:

- interests of potential competitors;

- political interests of parties and individual citizens;

- environmental extremism

Environmental organizations, using real problems or artificially creating them, manipulate public opinion and stimulate the population to protest activity. Addressing the threat (real or imaginary) to the life and health of the average citizen is one of the easiest ways to mobilize people of different political beliefs, with different income levels, social status, and different age groups. It is when using this technology that the critical understanding of information is disabled and the perception of the problem is transferred to the emotional plane. At the same time, a constructive compromise solution to the problem is both rejected and passed off as a desire of the authorities to "deceive the people", or formally compromise, but obviously unacceptable solutions are offered. The use of environmental issues to stimulate social protest inevitably leads to a reduction in investment, budget revenues and jobs.

Thus, the task of protecting nature is replaced by political and economic ones, when "environmentalists" actually act as an instrument of political or economic competition. Environmental protests are actively used in their selfish interests by both the countries opponents of Russia in the geopolitical and competitive struggle, and Russian political figures of various levels. One of the key tools in the hands of political ecologists in recent years has become legal technology, which is facilitated by the instability of the country's environmental legislation. The average validity period without changes in the environmental law in Russia is less than 5 months; in Belarus, Kazakhstan and the UK, changes are accepted 2-15 times less often [7].

The organizers of protest actions under the guise of environmental protection have been most active and continue to be active against objects aimed at ensuring import substitution in leading industries, preserving the energy independence of the Russian Federation, creating infrastructure facilities at the Federal and regional levels, reconstructing and modernizing enterprises in order to increase labor productivity and radically improve the quality of the environment.

Underestimation of social and environmental risks leads to conflicts, as a result of which the project requires additional financial investments, is delayed or suspended. At the same time, all parties to the conflict (the state, business, and the public concerned) suffer economic, reputational, and human losses.

Abroad, out of 32 cases of socio-environmental conflicts, only two of the three parties managed to agree and come to a unanimous decision. In 27 cases out of 34 (79\%), police with non-lethal weapons were used to disperse protesters against the implementation of investment projects, and in 4 cases (12\%) - the army. The result - 16 people were killed, 400 injured, and several tens of thousands were detained [8].

In Russia, the total damage from environmental protests amounted to more than 1 trillion rubles of potential investment [Ошибка! Закладка не определена.]. Over 10 years, 47 investment projects with a total investment volume of over 1.5 billion rubles have been stopped or suspended. Direct annual damage to the budget from lost tax revenues due to the blocking of construction and reconstruction of enterprises is estimated at 67.2-78.6 billion rubles. The number of uncreated new jobs only at these blocked facilities exceeds 56 thousand, and taking into account jobs in related industries, the number of lost jobs exceeds 480.7 thousand, which directly affects the interests of 1.8 million employees and their families [Ошибка! Закладка не определена.]. 
Average price for not taking into account the social and environmental risks of an investment project in Russia:

- the cost of the "frozen" project is 54.5 billion rubles/project;

- budget losses-2.5 billion rubles per year / project;

- uncreated jobs - 9 thousand people / project.

As an example of the difficulties faced by investors in Russia, let's look in more detail at the situation with the implementation of IP in the Sverdlovsk region.

The draft updated list of investment projects of strategic importance for the socioeconomic development of the Sverdlovsk region for 2019 includes 53 projects. This includes 36 projects from the 2018 list and 17 new ones. The amount of financial resources provided for the implementation of all projects is 1.5 trillion rubles. Implementation of the planned projects involves the creation of 24 thousand new jobs [9].

However, according to the RBC analysis, Yekaterinburg [10] over the past 2015 -2018, at least seven major investment projects were frozen or canceled in the region (table 1). The amount of lost profit for the region is about 40.4 billion rubles.

As a result of the termination or suspension of the IP, investors suffered significant losses: LLC Gross - 250 million rubles, LLC ProLime - 178 million rubles, PJSC Klyuchevsky Ferroalloy Plant - over 120 million rubles.

Table 1. Unrealized strategic investment projects of the Sverdlovsk region (2010-2018) [Ошибка! Закладка не определена.].

\begin{tabular}{|c|c|c|c|}
\hline № & Project & Investments & $\begin{array}{l}\text { Project implementation } \\
\text { period, years }\end{array}$ \\
\hline $1 \square$ & $\begin{array}{l}\text { LLC Gross. Enterprise for } \\
\text { processing } 10 \text { thousand tons of } \\
\text { antimony concentrates per year } \\
\text { to produce commercial metal } \\
\text { antimony, antimony trioxide, } \\
\text { gold-containing alloy }\end{array}$ & $\begin{array}{c}\text { Over } \\
1 \text { billion rubles }\end{array}$ & $2014-2018$ \\
\hline $2 \square$ & $\begin{array}{l}\text { LLC ProLime. Lime and } \\
\text { limestone processing plant based } \\
\text { on the South Mikhailovsky } \\
\text { limestone section }\end{array}$ & $\begin{array}{l}100 \text { billion U.S. } \\
\text { dollars }\end{array}$ & $2010-2016$ \\
\hline $3 \square \square$ & $\begin{array}{l}\text { LLC Mikhailovsky Quarry. } \\
\text { Cement plant with a capacity of } \\
1.2 \text { million tons / year. }\end{array}$ & 6677 thousand rubles & $2014-2018$ \\
\hline $4 \square \square$ & $\begin{array}{l}\text { Mit-Line Company and Anhui } \\
\text { Foreign Economic Construction } \\
\text { Group (AFECG). Cement plant } \\
\text { with a capacity of } 1.2 \text { million } \\
\text { tons / year. }\end{array}$ & 200 million euros & $2014-2018$ \\
\hline $\begin{array}{l}\square \square \\
\square \square\end{array}$ & $\begin{array}{l}\text { LLC "GRS Ural". Organization } \\
\text { of the production of } \\
\text { metalworking equipment }\end{array}$ & 3 150,0 тыс. руб. & $2016-2015$ \\
\hline $6 \square \square$ & $\begin{array}{l}\text { PJSC "Klyuchevsky Ferroalloy } \\
\text { Plant". Compact steel plant for } \\
\text { the production of special alloys } \\
\text { and steels }\end{array}$ & 6 billion rubles & 2016-2018 \\
\hline $\begin{array}{l}\square \square \square \\
\end{array}$ & $\begin{array}{l}\text { PJSC "Klyuchevsky Ferroalloy } \\
\text { Plant". Plant for the production } \\
\text { of aluminum powders. }\end{array}$ & 2 billion rubles & $2016-2018$ \\
\hline
\end{tabular}

$\square$ - suspended project, $\square \square$ - frozen project.

According to Ural businessmen, the region cannot provide investors with free passage of administrative barriers and does not help create favorable conditions for launching 
production. So, production of the third hazard class and higher in the Urals is faced with opposition from municipal public figures and deputies who use environmental rallies to form their image. The regional government prefers not to intervene in conflict situations and does not fulfill promises of investor support.

A typical example of the difficulties faced by investors in the implementation of IP in the Sverdlovsk region is the investment project of National Antimony Company LLC (NAC), an enterprise for the processing of 10 thousand tons of antimony concentrates per year to produce marketable metal antimony, antimony trioxide, and a gold-bearing alloy [11]. Investments in the project amounted to over 1 billion rubles. The planned implementation period is scheduled for $2014-2016$.

The NAC chose the first site in Degtyarsk (Sverdlovsk Region) in 2013, but due to environmental rallies, the investor was forced to transfer the project to the territory of the Asbest Plant of Metal Structures. The construction of the plant was planned to be launched in 2016. The Government of the Sverdlovsk region promised support and in 2015 introduced the project to the List of investment projects of strategic importance for the socio-economic development of the Sverdlovsk region.

In March 2017, rallies against the implementation of the project were held in Asbest and Degtyarsk. The organizer was a deputy of the City Duma from the Communist Party Natalia Krylova. At a public hearing, the deputy proposed changing the land use rules so that the NAC does not build a plant on the purchased territory. The Asbest City Duma implemented the deputy's proposal, in June 2017 the amendments entered into force, and the NAC lost the opportunity to create antimony production on the site due to changes in hazard class. The NAC appealed the lawfulness of these changes in the Sverdlovsk Regional Court and the Supreme Court of the Russian Federation, but to no avail.

Technologies used by opponents of the plant construction:

- Collecting 12 thousand signatures of residents of Asbestos (in total, 80 thousand people live in the city) under an appeal to Vladimir Putin to stop the construction of the plant [12].

- Attempts to hold a local referendum in Asbest against the construction of a plant. The previous composition of the Asbest City Duma (out of 20 deputies 13 are from United Russia) twice blocked the attempts of deputies from the Communist Party at the request of initiative groups of citizens to initiate a referendum on the construction of the plant [13].

- A rally of citizens against the construction of a plant on March 25, 2017 on Forum Square in Asbest, in which more than two thousand people took part (according to the organizers) [14].

- The lawsuit between the Asbest City Duma and Gross LLC (a subsidiary of NAC) [15].

- In October 2018, the National Antimony Company refused to sell IP in the Urals.

Thus, the effectiveness of the implementation of investment projects and the reduction of possible losses of investors can be achieved by real consideration of the socio-environmental risks. These risks can be reduced by using the following tools:

- introducing into legislation the definition of social and environmental risks;

- legislative streamlining of the activities of "eco-activists" with the introduction of strict standards of administrative and criminal liability for unreasonable actions aimed at developing social and environmental risks;

- clarification of the Federal Law of the Russian Federation No. 174 "On Ecological Expertise" [16] regarding the procedure for assessing the environmental impact, which, as part of a public environmental review, provides organizers of environmental protests with great opportunities for maneuvering during campaigns to counter major infrastructure projects;

- development of environmental insurance as a tool for managing social and environmental risks, which allows using international experience in involving the police and the judiciary; 
- use of public-private partnership (PPP) mechanisms at all stages of an investment project, including the initial one;

- involvement of public representatives in partnership of business and government by including in the framework of PPP the most active, environmentally literate citizens in the supervisory (expert) councils;

- widespread use of the media to inform society about the positive consequences of implementing an investment project, measures to minimize environmental risks, starting from the stages of choosing the location of an object and developing a feasibility study, increasing environmental literacy of the population;

- holding open hearings, working in labor collectives.

The proposed recommendations, according to the authors, will allow:

- more efficiently resolve conflicts, caused by socio-environmental risks, between business and government on the one hand and society on the other, and not provoke social tensions in certain regions;

- prevent economic losses associated with the suspension of the implementation of developed investment projects and potential projects, the development of which will be "frozen" by investors due to high unmanageable risks;

- implement investment projects aimed at the modernization and greening of production, ensuring sustainable development of Russian regions.

\section{References}

1. M.Yu. Molchanova, Bulletin of Perm University. Series: Economics, S. 45 (2012)

2. T.P. Filicheva, I.D. Gorkin, Economics of nature management and environmental protection (Vladivostok State University of Economics and Service, Vladivostok: Publishing House of VSUES, 2015)

3. Federal Law "On Environmental Protection" dated 10.01.2002 N 7-FZ (latest revision)) http://www.consultant.ru/document/cons_doc_LAW_34823/

4. I.P. Nuzhina, Regional Economics: theory and practice, 6, 64 (2010)

5. Death of a river, BBC, February 15, 2000 http://news.bbc.co.uk/2/hi/europe/642880.stm

6. D. Istomina, Ecologists recorded in foreign agents ( Rosbalt. Petersburg, 2018) http://www.rosbalt.ru/piter/2018/05/24/1705532.html

7. E. Usov, "Another Year of Ecology Wasted", "Echo of Moscow”, December 11, 2017 https://echo.msk.ru/blog/evgenyus/2108806-echo/

8. S. Mikheev, M. Zharov, I. Ryabov, Report of the expert group "Environmental protection and eco-aggression: political ecologists in Russia and the world. Technologies of environmental counteraction to the implementation of modern large-scale infrastructure projects in Russia" ( Moscow, 2018)

9. An updated list of strategic investment projects is presented on the investment council under the governor of the Sverdlovsk region, Official website of the Government of the Sverdlovsk region, http://midural.ru/news/list/document144311/

10. A. Abramova, RBC Monitoring: Sverdlovsk Region Loses $\$ 40$ Billion in Investments. Yekaterinburg. (2018) https://ekb.rbc.ru/ekb/18/10/2018/5bc8146a9a794780351a8154

11. "National Antimony Company" refused an investment project in the Urals. Yekaterinburg. (2018) https://ekb.rbc.ru/ekb/freenews/5bc478569a79478c23e60863.

12. "The plant was overlaid with evidence", "Kommersant", (2018), https://www.kommersant.ru/doc/3548774. 
13. "The referendum on the construction of an antimony plant in Asbest is postponed. Before updating the composition of the City Duma", ura.ru. (2017) https://ura.news/news/1052301482

14. "At least two thousand people participated in the protest action", Vedomosti-Ural, (2017) http://vedomosti-ural.ru/news/57003/

15. "This is the final victory! Of the City Duma of Asbest in the Supreme Court of the Russian Federation won the resonant case against the Rotenberg company to ban the construction of the scandalous antimony plant", Vedomosti-Ural, (2018) http://vedomosti-ural.ru/news/67505/

16. Federal Law 174 "On Environmental Expertise" of November 23, 1995 (as amended on May 1, 2019) http://docs.cntd.ru/document/9014668 